\title{
Atypical Clinical Manifestations of Acute Poststreptococcal Glomerulonephritis
}

\author{
Toru Watanabe \\ Department of Pediatrics, Niigata City General Hospital \\ Japan
}

\section{Introduction}

Acute poststreptococcal glomerulonephritis (APSGN) is one of the most common and important renal diseases resulting from a prior infection with group A $\beta$-hemolytic streptococcus (GAS) (Ash and Ingulli, 2008). Typical clinical features of the disease include an acute onset with gross hematuria, edema, hypertension and moderate proteinuria (acute nephritic syndrome) 1 to 2 weeks after an antecedent streptococcal pharyngitis or 3 to 6 weeks after a streptococcal pyoderma (Ahn \& Ingulli 2008; Rodriguez-Iturbe \& Mezzano, 2009). Gross hematuria usually disappears after a few days, while edema and hypertension subside in 5 to 10 days (Rodriguez-Iturbe \& Mezzano, 2009). Although the incidence of APSGN appears to be decreasing in industrialized countries, more than 472,000 cases with APSGN are estimated to occur each year worldwide, with $97 \%$ of them occurring in developing countries (Carapetis et al., 2005; Eison et al., 2010).

APSGN occurs most commonly in children, 5 to 12 years old (Ahn \& Ingulli, 2008), although 5 to 10 percent of the patients are more than 40 years old (Yoshizawa, 2000). The immediate and long-term prognoses of APSGN are excellent for children, assuming it is diagnosed in a timely fashion (Kasahara et al., 2001, Rodriguez-Iturbe \& Musser, 2008). In contrast, adult patients with APSGN show markedly worse prognoses both in the acute phase and in the long-term (Rodriguez-Iturbe \& Musser, 2008).

The most popular theory of the pathogenic mechanism of APSGN has been the immunecomplex theory, which involves the glomerular deposition of nephritogenic streptococcal antigen and subsequent formation of immune complexes in situ and/or the deposition of circulating antigen-antibody complexes (Oda et al., 2010). Two antigens have been actively investigated as the potential causes of APSGN (Rodriguez-Iturbe \& Musser, 2008): the nephritis-associated plasmin receptor (NAPlr) also known as streptococcal glyceraldehyde-3-phosphate dehydrogenase (Yamakami et al., 2000; Yoshizawa et al., 2004), and a cationic cysteine proteinase known as streptococcal pyogenic exotoxin B (SPEB) (Batsford et al., 2005).

Patients with APSGN sometimes exhibit atypical or unusual clinical manifestations, which may lead to diagnostic delay or misdiagnosis of the disorder (Eison et al. 2011; Pais et al. 2008). Recognition of these unusual manifestations in cases of APSGN is important in order to assure that the patient receives adequate treatment. In this chapter, I review the atypical clinical manifestations of APSGN. 


\section{Atypical manifestations of APSGN}

Atypical manifestations of APSGN can be classified as the following: co-occurrence of immune-mediated diseases; non immune-mediated complications; and unusual clinical presentations or courses (Table 1).

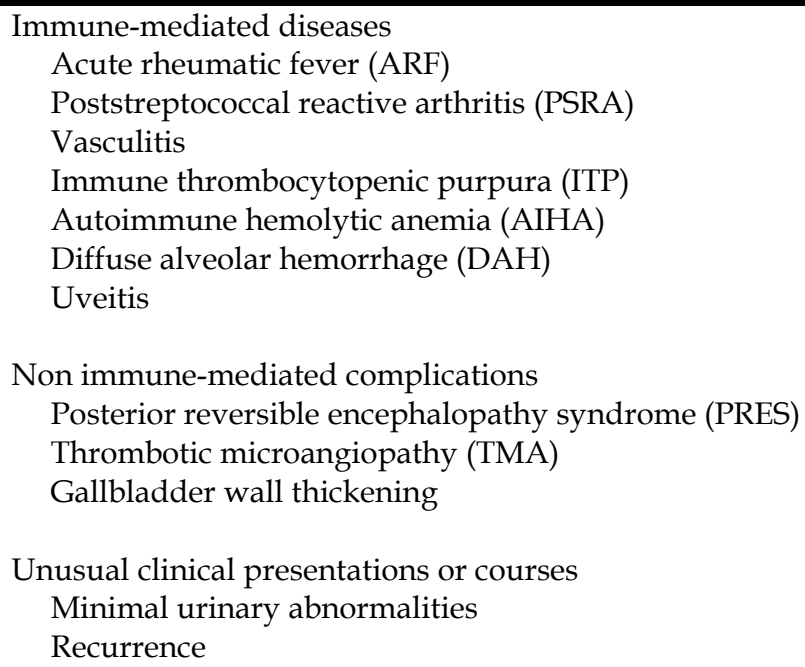

Table 1. Atypical manifestations of acute poststreptococcal glomerulonephritis

\subsection{Immune-mediated diseases}

Immune-mediated diseases most likely result from immune-complex formation between streptococcal antigens and their associated antibodies, and include acute rheumatic fever, poststreptococcal reactive arthritis, vasculitis, immune thrombocytopenic purpura, autoimmune hemolytic anemia, diffuse alveolar hemorrhage and uveitis.

\subsubsection{Acute rheumatic fever}

Acute rheumatic fever (ARF) is an autoimmune disease that follows infection by GAS and is characterized by inflammation of several tissues that gives rise to typical clinical characteristics (the so-called Jones criteria) including carditis/valvulitis, arthritis, chorea, erythema marginatum, and subcutaneous nodules (Steer \& Carapetis, 2009). ARF is rare in developed countries, but it remains common in developing countries and some poor, mainly indigenous populations of wealthy countries (Steer \& Carapetis, 2009; Carapetis et al., 2005).

Although both ARF and APSGN develop following GAS infection, the two diseases have different epidemiology, immunology and bacteriology, and simultaneous occurrence of them in the same patient is rare (Lin et al., 2007). Since Gibney et al. first reported a patient with co-occurrence of ARF and histologically proven APSGN (Gibney et al., 1981), seventeen patients with concurrent ARF and APSGN have been reported (Akasheh et al., 1995; Ben-Dov et al., 1985; Castillejos et al., 1985; Imanaka et al., 1995; Kakkera et al., 1998; Kujala et al., 1989; Kula et al., 2003; Kwong et al., 1987; Lin et al., 2003; Mastell et al., 1990; Öner, et al., 1993; Said et al., 1986; Sieck et al., 1992; Sinha et al., 2007). 
Fourteen patients were children and ten were male. Eight patients initially presented with ARF preceding APSGN, 3 patients suffered from ARF following the development of APSGN and both ARF and APSGN simultaneously occurred in 6 patients. Although many patients showed carditis (16 out of 17 patients) and polyarthritis (13 out of 17 patients), the remaining characteristics (erythema marginatum, chorea and subcutaneous nodules) developed in only 4 patients, 1 patient and 1 patient, respectively.

Although it remains unclear why simultaneous occurrence of APSGN and ARF is so rare, one explanation may be that only few streptococcal strains have both nephritogenic and rheumatogenic antigenic features (Lin et al., 2003).

\subsubsection{Poststreptococcal reactive arthritis}

Poststreptococcal reactive arthritis (PSRA) is defined as acute arthritis of more than 1 joint following an episode of GAS infection in a patient whose illness does not fulfill the Jones criteria for the diagnosis of ARF (Barash et al., 2008; Gerber M, 2007). It remains controversial whether or not PRSA and ARF are distinct entities or not (Gerber M, 2007). Mackie and Keat reviewed 188 published cases of PSRA and concluded that PSRA was a heterogenous group of clinical entities (Mackie \& Keat, 2004). However, two recent studies suggested that PSRA and ARF were separate disease entities on the basis of the differences in clinical presentation and disease course (Barash et al., 2008; van der Helm-van Mil, 2010). Compared to patients with ARF, patients with PSRA are older, respond poorer to salicylates and have non-migratory and persistent arthritis (Tokura et al., 2008; van der Helm-van Mil, 2010). The precise pathogenic mechanism underlying the development of PSRA is unclear, production of antistreptococcal antibodies that cross-react with human epitopes causing inflammation and tissue damage is a likely pathogenic mechanism for PSRA, as has been proposed for ARF (Niewold \& Ghosh, 2003).

Simultaneous occurrence of PSRA and APSGN is rare, with only 3 cases having been reported (Niewold \& Ghosh, 2003; Sugimoto et al., 2008; Tokura et al., 2008). Niewold \& Ghosh described a 44-year-old man who developed severe PSRA and APSGN after a subclinical streptococcal infection (Niewold \& Ghosh, 2003). Tokura et al. reported a 16-year-old man who presented with simultaneous occurrence of APSGN and PSRA with symmetric persistent tenosynovitis in hands and feet (Tokura et al., 2008). Sugimoto et al. described a 61-year-old man who exhibited PSRA and APSGN with marked renal interstitial inflammation after bacterial endophthalmitis due to Streptococcus pyogenes (Sugimoto et al., 2008). Arthritis of all the patients improved with corticosteroid therapies without any sequellae.

\subsubsection{Vasculitis}

Vasculitis is not a well-recognized condition associated with GAS infection, but there have been several reports of Henoch-Schönlein purpura (HSP) (al-Sheyyab et al., 1999) or Henoch-Schönlein purpura with nephritis (HSPN) (Masuda et al., 2003), cutaneous leukocytoclastic vasculitis (Chalkias et al, 2010), vasculitic neuropathy (Traverso et al., 1997), polyarteritis nodosa (PN) (David et al., 1993) and unclassified systemic vasculitis (Lucas \& Moxham, 1978). Although the precise pathogenic role of GAS infection contributing to the development of vasculitis remains unclear, an immune complex-mediated mechanism triggered by GAS infection has been postulated (Ritt M. et al., 2006).

Vasculitides including cutaneous vasculitis mimicking HSP, cerebral vasculitis, PN, necrotizing vasculitis and Wegener's granulomatosis have been described to occur in patients with APSGN. 
HSP is an IgA immune complex-mediated systemic leukocytoclastic vasculitis of small vessels that primarily affects the skin, gastrointestinal tract, joints and kidney (Dedeoglu \& Sundel, 2007; Robson \& Leung , 1994). Respiratory infections with GAS preceding the onset of HSP have been reported in up to one-third of cases (Dedeoglu \& Sundel, 2007). APSGN patients simultaneously presenting with HSP or vasculitis mimicking HSP are rare and only five patients have been reported. Goodyer et al. described two boys with histologically proven APSGN, in whom cutaneous vasculitis and abdominal symptoms mimicked HSP (Goody et al., 1978). Onisawa et al. reported a patient with concurrent APSGN and cutaneous leukocytoclastic vasculitis without IgA deposition (Onisawa et al., 1989). Maruyama et al. presented a patient with congenital complement 9 deficiency exhibiting biopsy-proven APSGN and clinical symptoms mimicking HSP (Maruyama et al., 1995). Matsukura et al. also described a 20-month-old girl with biopsy-proven APSGN, who presented with cutaneous vasculitis mimicking HSP (Matsukura et al., 2003). All patients recovered completely without any sequellae.

Central nervous system abnormalities of APSGN are usually secondary to acute severe hypertension, electrolyte disturbances or uremia, but can also be attributed to cerebral vasculitis (Dursun et al., 2008; Ritt et al., 2006). To date, five cases of cerebral vasculitis associated with APSGN have been reported (Dursun et al., 2008; Kaplan et al., 1993; Ritt et al., 2006; Rovang et al., 1997; Wong \& Morris, 2001), in which 4 patients were children. Clinical features of cerebral vasculitis in APSGN include severe headache with nausea and vomiting, transient focal neurological signs, visual disturbances, and seizures. Although the computed tomography of the brain may not detect abnormalities, the magnetic resonance imaging of the brain often demonstrated multiple supratentorial areas of abnormal signal intensity in the white and adjacent grey matter (Dursun et al., 2008). All patients underwent corticosteroid therapy (three of them commenced on methylprednisolone pulse therapy) and recovered without any neurological sequellae.

$\mathrm{PN}$ is a necrotizing vasculitis affecting the medium-sized muscular arteries (Dillon et al., 2010). Five patients with co-occurrence with PN and APSGN have been described. Fordham et al. reported three young adult patients with both PN and APSGN, two of whom died secondary to multi-system organ failure (Fordham et al., 1964). Blau et al. described two children with PN who also had serological and clinical evidence of APSGN (Blau et al., 1977).

Although extremely rare, necrotizing vasculitis other than PN (Bodaghi et al., 1987; Ingelfinger et al., 1977) and Wegener's granulomatosis (Garrett et al., 1993) has also been reported in patients with APSGN.

\subsubsection{Immune thrombocytopenic purpura}

Immune thrombocytopenic purpura (ITP) is an immune-mediated acquired disorder in which antiplatelet antibodies cause accelerated destruction of platelets, resulting in thrombocytopenia and an increase risk of bleeding (Psaila \& Bussel, 2007). Childhood ITP often occurs following an infection with viruses such as varicella zoster, rubella, Epstein-Barr, influenza, or human immunodeficiency virus (Tasic \& Polenakovic, 2003), but may also be preceded by a bacterial infection (Muguruma et al., 2000). Recently, a number of studies have suggested an association between Helicobacter pylori and ITP (Cooper \& Bussel, 2006).

Since Kaplan and Esseltine first reported ITP in two patients with APSGN (Kaplan \& Esseltine, 1978), five cases of ITP in patients with APSGN have been reported (Muguruma et al., 2000; Rizkallah et al., 1984; Tasic \& Polenakov, 2003). All patients were children (4 to 7 years of age) who underwent corticosteroid therapy and fully recovered from APSGN and 
ITP. One patient exhibited a marked increase in platelet-associated immunoglobulin G level (Muguruma et al., 2000). Although the precise pathogenic mechanism for the development of ITP in patients with APSGN is unclear, Muguruma et al. speculated about the pathogenesis of associated diseases through production of autoantibodies cross-reactive against GAS and against platelets (Muguruma et al., 2000).

\subsubsection{Autoimmune hemolytic anemia}

Anemia is common in APSGN and traditionally it has been attributed solely to volume overload (Eison et al., 2011). However, autoimmune hemolytic anemia (AIHA) has recently been reported in patients with APSGN. AIHA is a clinical condition in which IgG and/or IgM antibodies bind to red blood cells (RBC) surface antigens and initiate RBC destruction via the complement system and the reticuloendothelial system (Gehrs \& Friedberg, 2002). Subtypes include warm AIHA, cold AIHA, mixed-type AIHA and drug-induced immune hemolytic anemia. Furthermore, cold AIHA has been categorized into cold agglutinin syndrome (CAS) and paroxysmal cold hemoglobinuria (PCH). Infectious agents associated with CAS or PCH include Mycoplasma pneumonia, Epstein-Barr virus, adenovirus, cytomegalovirus, influenza viruses, human immunodeficiency virus, measles, mumps, Escherichia coli, Listeria monocytogenes, Haemophilus influenza and Treponema pallidum (Gehrs \& Friedberg, 2002).

Greenbaum et al. described three children with both APSGN and cold AIHA, two of whom had an anti-I autoantibody and thereby were diagnosed with CAS (Greenbaum et al., 2003). Two patients were transfused and all patients recovered from AIHA and APSGN. Cachat et al. presented a 10-year-old child with concurrent cold AIHA and APSGN, who developed anuric acute renal failure and profound anemia (Cachat et al., 2003). The patient responded well to corticosteroid therapy and had a full renal and hematological recovery.

\subsubsection{Diffuse alveolar hemorrhage}

Diffuse alveolar hemorrhage (DAH) is sometimes accompanied by glomerulonephritis, and is often referred to as pulmonary-renal syndrome (Papiris et al., 2007). Pulmonary-renal syndromes include Goodpasture's syndrome, antineutrophil cytoplasmic antibodyassociated vasculitis, immune complex-associated glomerulopathy and thrombotic microangiopathy (Papiris et al., 2007).

DAH associated with APSGN is extremely rare and only three patients have been reported. Chugh et al. described a 38-year-old-male with concurrent DAH and crescentic APSGN who progressed to end-stage renal failure (Chugh et al., 1981). Gilboa et al. reported a 12-year-old girl who exhibited a noncrescentic APSGN and DAH (Gilboa et al., 1993). Sung et al. recently described a 59-year-old-woman with APSGN and DAH (Sung et al., 2007). DAH in all three patients subsided after intravenous corticosteroid therapies. The pathogenic mechanism of DAH in APSGN remains unclear.

\subsubsection{Uveitis}

Uveitis is believed to be an immunological response to exogenous and endogenous antigens (Leiba et al., 1998) and can occur following GAS infection, so-called "poststreptococcal uveitis". Since Cokingtin \& Han reported the first case of poststreptococcal uveitis in 1991 (Cokingtin \& Han, 1991), several patient reports and case series with poststreptococcal uveitis have been presented (Leiba et al., 1998, Ur Rehman et al., 2006). 
Feldon et al. recently reported the first case of a child with concomitant APSGN and uveitis, whose uveitis subsided within a few days with topical corticosteroid and mydriatic treatment (Feldon et al., 2010).

\subsection{Non immune-mediated complications}

Non immune-mediated complications of APSGN include posterior reversible encephalopathy syndrome, thrombotic microangiopathy and gallbladder wall thickening.

\subsubsection{Posterior reversible encephalopathy syndrome}

Posterior reversible encephalopathy syndrome (PRES), also known as reversible posterior leukoencephalopathy syndrome (RPLS), is a recently described brain disorder associated with findings on neuroimaging that suggest white-matter edema, mostly in the posterior parietal-temporal-occipital regions of the brain (Hinchey et al., 1996). However, radiological lesions in PRES are rarely isolated to these areas, and often involve the cortex, frontal lobes, basal ganglia and brainstem (Fugate et al., 2010) (Fig. 1).
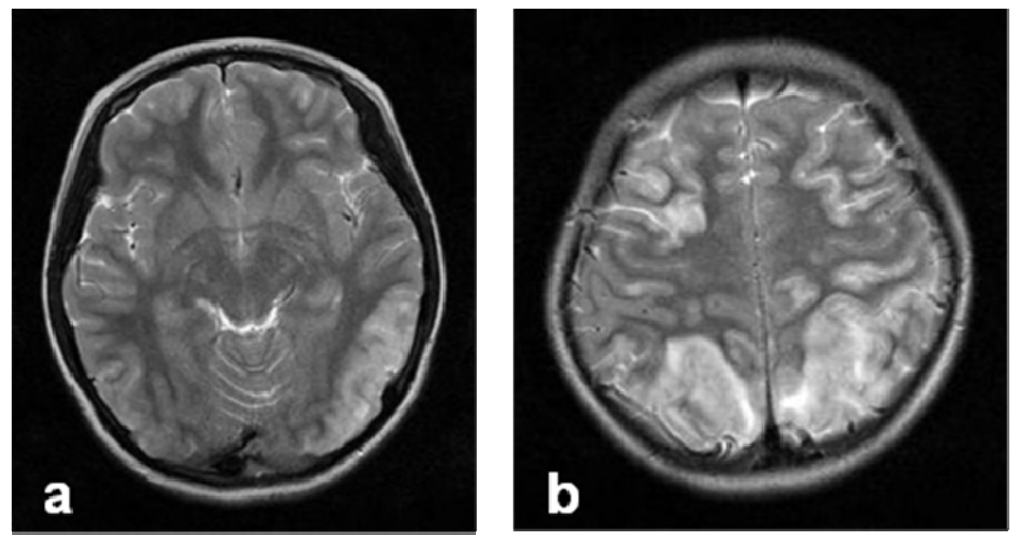

Fig. 1. Magnetic resonance images (MRI) of the brain (T2-weighted image) showing increased intensity in the cortex and subcortical white matter of left occipital (a), bilateral parietal and right frontal lobes (b), consistent with PRES.

The clinical characteristics of the disease include headache, decreased alertness, altered mental functioning, seizures, and visual loss including cortical blindness (Hinchey et al., 1996). The syndrome has been associated with acute hypertension, preeclampsia or eclampsia, glomerulonephritis, sepsis, autoimmune disorders and immunosuppressive or chemotherapeutic treatments (Bartynski, 2008a; Hinchey et al., 1996). Although the underlying pathophysiology of PRES remains elusive, three theories have been proposed: 1) hypertension-induced breakdown in cerebral auto-regulation; 2) cerebrovascular endothelial dysfunction and; 3) vasoconstriction and hypoperfusion with subsequent ischemia and vasogenic edema (Bartynski, 2008b; Fugate et al., 2010). The preferential involvement of the posterior brain in PRES may be caused by its relative paucity of sympathetic innervation in comparison to the anterior circulation (Froehlich et al., 1999). The outcome of PRES is generally favorable, but delay in initiating the appropriate treatment may result in permanent damage to the brain (Fux et al., 2006; Garg, 2001). 
While it is estimated that PRES occurs in 5\% to $10 \%$ of children hospitalized with acute glomerulonephritis of all etiologies, the prevalence of PRES associated with APSGN is unknown (Froehlich et al., 1999). PRES caused by hypertension has been reported in 7 children (from 7 to 15 years of age) with APSGN (Froehlich et al., 1999; Fux et al., 2006; Guputa et al., 2010; Nordby, 1997; Özcakar et al., 2004; Soylu et al., 2001). Six patients complained of headache, 5 exhibited decreased alertness and seizures, and 3 had altered mental functioning and visual loss. All patients exhibited abnormal findings of the brain MRI or CT in the white matter of the parietal and occipital lobes, and recovered without any neurological sequellae following adequate treatment of the associated hypertension.

One patient with APSGN suffered from PRES without severe hypertension (Nordby, 1997). The most important factor in development of pediatric hypertensive PRES is the rapidity of blood pressure elevation and the degree of elevation relative to the patient's baseline pressure (Froehlich et al., 1999). It has been suggested that blood pressures more than $30 \%$ above normal for age should alert clinicians to the possibility of hypertensive PRES (Nordby, 1997).

\subsubsection{Thrombotic microangiopathy}

Thrombotic microangiopathy (TMA) is a pathological term used to describe occlusive microvascular thrombus formation and is most commonly associated with hemolytic uremic syndrome (HUS) and thrombotic thrombocytopenic purpura (TTP) (Keir \& Coward, 2010). Pathological features of TMA include vessel wall thickening, swelling and detachment of the endothelial cell from the basement membrane, accumulation of material in the subendothelial space, intraluminal platelet thrombosis, partial or complete vessel luminal obstruction and fragmentation of red blood cells (Keir \& Coward, 2010). HUS is defined as the triad of microangiopathic hemolytic anemia, thrombocytopenia, and acute renal injury (Copelovitch \& Kaplan, 2008). TTP is characterized by the pentad of microangiopathic hemolytic anemia, thrombocytopenia, fever, acute renal injury, and neurological abnormalities (Copelovitch \& Kaplan, 2008).

TMA has been reported in 8 patients with APSGN, consisting of 5 children and 3 adults (Duvic et al., 2000; Izumi, et al., 2005; Laube, et al., 2001; Medani et al., 1987; Proesmans, 1996; Siebels et al., 1995; Tan et al., 1998). All patients exhibited severe hypertension. Hemodialysis or peritoneal dialysis was required in 2 patients. Renal biopsy showed histological features of both APSGN and TMA in 3 patients, and revealed characteristics of APSGN without features of TMA in 5 patients. The outcome in all patients was excellent.

The precise pathogenesis of TMA in patients with APSGN is unclear, although two causes have been postulated: severe hypertension and streptococcal neuraminidase (Duvic et al., 2000; Laube et al., 2001; Izumi et al., 2005). HUS has been reported as a complication of severe hypertension, regardless of the cause (Broyer, 1995). If severe hypertension is transient, histological lesions of TMA are absent. When hypertension becomes malignant, renal histological lesions show features of TMA (Duvic et al., 2000). Another possible cause of TMA in APSGN is alteration of vascular endothelial cells by streptococcal neuraminidase. Circulating neuraminidase causes exposure of the cryptic T-antigen on cell surfaces, to which most people possess a naturally occurring antibody. Therefore antigen-antibody interaction may damage the vascular endothelial cells leading to the clinical manifestations of HUS (Izumi et al., 2005). 


\subsubsection{Gallbladder wall thickening}

Thickening of the gallbladder wall is the most common findings in acute cholecystitis, but it has also been reported in patients with kidney diseases including pyelonephritis (Talarico \& Rubens, 1990) and chronic kidney failure (van Breda Vriesman et al., 2007). Only one child with APSGN and gallbladder wall thickening has been reported (Watanabe \& Baba, 2009). Although the pathogenesis of this complication is unclear, elevated systemic venous pressure or subclinical vasculitis may have caused edema of the gallbladder wall (Watanabe \& Baba, 2009).

\subsection{Unusual clinical presentations or courses}

Unusual clinical presentations or courses of APSGN include acute nephritic syndrome with minimal urinary abnormalities, and recurrence of the disease.

\subsubsection{Minimal urinary abnormalities}

Patients with APSGN usually exhibit hematuria and proteinuria. However, Blumberg and Feldman first reported two children with biopsy-proven APSGN without any urinary abnormalities (Blumberg \& Feldman, 1962). Thereafter, several authors described biopsyproven APSGN patients with minimal or no urinary abnormalities including 13 children and 4 adult patients (Albert et al., 1966; Cohen \& Levitt, 1963; Dunn, 1967; Fujinaga et al., 2007; Goorno et al., 1967; Grossman et al., 1973; Hoyer et al., 1967; Kandall et al., 1969; Kobayashi et al., 1971). All patients exhibited edema and hypertension, and seven showed pulmonary edema or congestion. Hypertensive encephalopathy occurred in one patient (Hoyer et al., 1967) and acute rheumatic fever developed in another patient (Cohen \& Levitt, 1963). All patients recovered completely without any sequellae. The mechanism for the elaboration on normal or minimal urinary abnormalities during the course of APSGN is unclear (Fujinaga et al., 2007; Kandall et al., 1969).

\subsubsection{Recurrence}

Recurrence of APSGN is a well-recognized, but relatively rare phenomenon, probably due to the relatively limited number of nephritogenic strains of streptococci and the acquisition of protective immunity against a nephritogenic streptococcal antigen after an initial episode of APSGN (Watanabe \& Yoshizawa, 2001). Ramberg first mentioned this condition and reported eleven patients with the recurrent attacks out of 152 patients with APSGN (Ramberg, 1947). Thereafter, several clinical studies of APSGN have suggested an incidence of recurrent APSGN that ranges from 0.7\% to 7.0\% (Baldwin D et al., 1974; Bernstein et al., 1960; Dodge W. et al., 1968; Sanjad et al., 1977; Roy et al., 1969). In addition, a few case reports of recurrent APSGN have been described (Casquero et al., 2006; Derakhshan 2002; Kim et al., 1979; Rosenberg et al., 1984; Velhote et al., 1986; Watanabe \& Yoshizawa, 2001). Clinical features and outcomes were well-described in 35 patients including 22 children. Most patients suffered from one recurrent episode, but one patient exhibited 2 recurrent attacks of APSGN (Velhote et al., 1986). Twenty-nine patients recovered completely, whilst 4 patients continued to have some urinary abnormalities and two patients progressed to endstage renal failure.

Although the exact mechanism leading to recurrence of APSGN has not yet been determined, three possible explanations have been postulated: the suppression of immune response against nephritogenic streptococcal strains due to early antibiotic therapy (Roy et 
al., 1969; Sanjad et al., 1977); an absence of natural immune responses against nephritogenic streptococcal components without antibiotic therapy (Watanabe \& Yoshizawa, 2001), and; a failure to exclude microbial agents through the digestive and respiratory tract due to $\operatorname{IgA}$ deficiency (Casquero et al., 2006).

Sanjado et al. suggested that reinfection with the same type of Streptococcus would occur if the patient lacked antibodies against that particular type, and penicillin therapy given in the first ten days after a streptococcal infection suppressed the formation of type-specific immunity conferring antibodies, which might increase the chances of re-infection with the same nephritogenic strain responsible for the initial episode of APSGN (Sanjad et al., 1977). Recently, Yoshizawa et al. identified a new nephritogenic streptococcal antigen and termed it nephritis-associated plasmin receptor (NAPlr) (Yamakami et al., 2000; Yoshizawa et al., 2004). They demonstrated that most patients with APSGN had high titers of long-lasting antibody against NAPlr and that it was present in glomeruli in $100 \%$ of patients with APSGN early in the disease (Yoshizawa et al., 2004). Watanabe and Yoshizawa described an 8-year-old boy with recurrent ASPGN who did not have serum antibodies against NAPlr, even though NAPlr was detected in glomeruli of an early kidney biopsy specimen from the patient during the second attack of APSGN. These results indicated that recurrence of APSGN in some patients might be caused by an absence of a natural immune response to NAPlr (Watanabe \& Yoshizawa, 2001).

Recently, Casquero et al. published a patient with selective IgA deficiency who experienced two episodes of APSGN (Casquero et al., 2006), suggesting that a failure of IgA defenses might also predispose to streptococcal re-infection and cause recurrent APSGN.

\section{Conclusions}

Patients with APSGN sometimes exhibit atypical or unusual clinical manifestations, which are divided into 3 categories: immune-mediated diseases (ARF, PSRA, vasculitis, ITP, AIHA, DAH and uveitis), non-immune mediated conditions (PRES, TMA and gallbladder wall thickening), and unusual clinical presentations or courses (minimal urinary abnormalities and recurrence).

Immune-mediated diseases seem to result from immune-complex formation between streptococcal antigens and their associated antibodies. Hypertension contributes to the development of PRES and TMA, while fluid retention results in PRES and gallbladder wall thickening. Recurrence of APSGN may be the consequence of suppressed immune responses against nephritogenic streptococcal strains caused by early antibiotic therapy, by the absence of natural immune responses against NAPlr, or by selective IgA deficiency.

Because atypical or unusual manifestations of APSGN may lead to diagnostic delays or misdiagnosis of the disorder, recognition of them is important in order to assure that the patient receives adequate treatment.

\section{References}

Ahn S., Ingulli E. (2008). Acute poststreptococcal glomerulonephritis: an update. Current Opinion in Pediatrics, Vol.20, No.2, (April 2008), pp. 157-162, ISSN 1040-8703

Akasheh M., al-Lozi M., Affarah H., Hajjiri F. al-Jitawi S. (1995). Rapidly progressive glomerulonephritis complicating acute rheumatic fever. Postgraduate Medical Journal, Vol.71, No.839, (September 1995), pp. 553-554, ISSN 0032-5473 
Albert M., Leeming J. \& Scaglione P. (1966). Acute glomerulonephritis without abnormality of the urine. Journal of Pediatrics, Vol.68, No.4, (April 1966), pp. 525-529, ISSN 00223476

al-Sheyyab M., Batieha A., el-Shanti H. \& Daoud A. (1999). Henoch-Schönlein purpura and streptococcal infection: a prospective case-control study. Annals of Tropical Paediatrics, Vol.19, No.3, (September 1999), pp. 253-255, ISSN 0272-4936

Baldwin D., Gluck M., Schacht R. \& Gallo G. (1974). The long-term course of poststreptococcal glomerulonephritis. Annals of Internal Medicine, Vol.80, No.3, (March 1974), pp. 342-358, ISSN 0003-4819

Barash J., Mashiach E., Navon-Elkan P., Berkun Y., Harel L., Tauber T., Padeh S., Hashkes P. \& Uziel Y. (2008). Differentiation of post-streptococcal reactive arthritis from acute rheumatic fever. Journal of Pediatrics, Vol.153 No.5, (November 2008), pp. 696-699, ISSN 0022-1476

Bartynski W. (2008a). Posterior reversible encephalopathy syndrome, part 1: fundamental imaging and clinical features. American Journal of Nueroradiology, Vol.29, No.6, (June 2008), pp. 1036-1042, ISSN 0915-6108

Bartynski W. (2008b). Posterior reversible encephalopathy syndrome, part 2: controversies surrounding pathophysiology of vasogenic edema. American Journal of Nueroradiology, Vol.29, No.6, (June 2008), pp. 1043-1049, ISSN 0915-6108

Batsford S., Mezzano S., Mihatsch M., Schiltz E. \& Rodriguez-Iturbe B. (2005). Is the nephritogenic antigen in post-streptococcal glomerulonephritis pyogenic exotoxin B (SPE B) or GAPDH? Kidney International, Vol.68, No.3, (September 2005), pp. 1120-1129, ISSN 0085-2538

Ben-Dov I., Berry E. \& Kopolovic J. (1985). Poststreptococcal nephritis and acute rheumatic fever in two adults. Archives of Internal Medicine, Vol.145, No.2, (February 1985), pp. 338-339, ISSN 0003-9926

Bernstein S. \& Stillerman M. (1960). A study of the association of group A streptococci with acute glomerulonephritis. Annals of Internal Medicine, Vol.52, (May 1960), pp. 10261034, ISSN 0003-4819

Blau E., Morris R. \& Yunis E. Polyarteritis nodosa in older children. Pediatrics, Vol.60, No.2, (August 1977), pp. 227-234, ISSN 0031-4005

Blumberg R. \& Feldman D. (1962). Observations on acute glomerulonephritis associated with impetigo. Journal of Pediatrics, Vol.60, (May 1962), pp. 677-685, ISSN 0022-3476

Bodaghi E., Kheradpir K. \& Maddah M. (1987). Vasculitis in acute streptococcal glomerulonephritis. International Journal of Pediatric Nephrology, Vol.8, No.2, (AprilJune 1987), pp. 69-74, ISSN 0391-6510

Broyer M. (1995). Commentary. Pediatric Nephrology, Vol.9, No.3, (June 1995), pp. 392-394, ISSN 0931-041X

Cachat F., Dunsmore K. \& Tufro A. (2003). Concomitant anuric post-streptococcal glomerulonephritis and autoimmune hemolytic anemia. European Journal of Pediatrics, Vol.162, No.7-8, (July 2003), pp. 552-553, ISSN 0340-6199ah

Carapetis J., Steer A., Mulholland E., \& Weber M. (2005). The global burden of group A streptococcal diseases. Lancet Infectious Disease, Vol.5, No.11, (November 2005), pp. 685-694, ISSN 1473-3099

Carapetis J., McDonald M. \& Wilson N. (2005). Acute rheumatic fever. Lancet, Vol. 366, No. 9480, (July 2005), pp. 155-168, ISSN 0140-6736 
Casquero A., Ramos A., Barat A., Mampaso F., Caramelo C., Egido J. \& Oriz A. (2006). Recurrent acute postinfectious glomerulonephritis, Clinical Nephrology, Vol.66, No.1, (July 2006), pp. 51-53, ISSN 0301-0430

Castillejos G., Padilla L., Lerma A., González S. \& Reyes P. (1985). Coincidence of acute rheumatic fever and acute post streptococcal glomerulonephritis. Journal of Rheumatology, Vol.12, No.3, (June 1985), pp. 587-589, ISSN 0263-7103

Chalkias S., Samson S., Tiniakou E. \& Sofair S. (2010). Poststreptococcal cutaneous leukocytoclastic vasculitis: a case report. Connecticut Medicine, Vol.74, No.7, (August 2010), pp. 399-402, ISSN 0010-6178

Chugh K., Gupta V., Singhal P. \& Sehgal S. (1981). Case report: poststreptococcal crescentic glomerulonephritis and pulmonary hemorrhage simulating Goodpasture's syndrome. Annals of Allergy, Vol.47, No.2, (August 1981), pp. 104-106, ISSN 00034738

Cohen J. \& Levitt M. (1963). Acute glomerulonephritis with few urinary abnormalities. Report of two cases proved by renal biopsy. New England Journal of Medicine, Vol.268, (April 1963), pp. 749-753, ISSN 0028-4793

Cokingtin C. \& Han D. (1991). Bilateral nongranulomatous uveitis and a poststreptococcal syndrome. American Journal of Ophthalmology, Vol.112, No.5, (November 1991), pp. 595-596, ISSN 0002-9394

Cooper N. \& Bussel J. (2006). The pathogenesis of immune thrombocytopenic purpura. British Journal of Haematology, Vol.133, No.4, (May 2006), pp. 364-374, ISSN 00071048

Copelovitch L. \& Kaplan B. (2008). The thrombotic microangiopathies. Pediatric Nephrology, Vol.23, No.10, (October 2008), pp. 1761-1767, ISSN 0931-041X

David J., Ansell B. \& Woo P. (1993). Polyarteritis nodosa associated with streptococcus. Archives of Disease in Childhood, Vol.69, No.6, (December 1993), pp. 685-688, ISSN 0003-9888

Dedeoglu F. \& Sundel R. (2007). Vasculitis in children. Rheumatic Diseases Clinics of North America, Vol.33, No.3, (August 2007), pp. 555-583, ISSN 6889-857X

Derakhshan A. (2002). Another case of acute poststreptococcal glomerulonephritis with recurrence. Pediatric Nephrology, Vol.17, No.6, (June 2002), pp. 462, ISSN 0931-041X

Dillon M., Eleftheriou D. \& Brogan P. (2010). Medium-size-vessel vasculitis. Pediatric Nephrology, Vol.25, No.9, (September 2010), pp. 1641-1652, ISSN 0931-041X

Dodge W., Spargo B., Basss J. \& Travis L. (1968). The relationship between the clinical and pathologic features of poststreptococcal glomerulonephritis. A study of the early natural history. Medicine, Vol.47, No.3, pp. 227-267, ISSN 0025-7974

Dunn M. (1967). Acute glomerulonephritis with normal results from urinalyses. A report of two cases and comments on four additional cases with atypical findings from urinalyses. Journal of the American Medical Association, Vol. 201, No.12, (September, 1967), pp. 933-937, ISSN 0098-7484

Dursun I., Gunduz Z., Poyrazoglu H., Gumus H., Yilkilmaz A. \& Dusunsel R. (2008). Cerebral vasculitis and unilateral sixth-nerve palsy in acute post-streptococcal glomerulonephritis. Annals of Tropical Paediatrics, Vol.28, No.2, (June 2008), pp. 155-159, ISSN 0272-4936 
Duvic C., Desramé J., Hérody M. \& Nédélec G. (2000). Acute poststreptococcal glomerulonephritis associated with thrombotic microangiopathy in an adult. Clinical Nephrology, Vol.54, No.2, (August 2000), pp. 169-173, ISSN 0301-0430

Eison T., Ault B., Jones D., Chesney R., \& Wyatt R. (2011). Post-streptococcal acute glomerulonephritis in children: clinical features and pathogenesis. Pediatric Nephrology, Vol.26, No.2 (February 2011), pp. 165-180, ISSN 0931-041X

Feldon M., Dorfman L., Tauber T., Morad Y., Bistritzer T. \& Goldman M. (2010). Poststreptococcal glomerulonephritis and uveitis - a case report. Pediatric Nephrology, Vol.25, No.11, (November 2010), pp. 2351-2353, ISSN 0931-041X

Fordham C. III, Epstein F., Huffines W. \& Harrington J. (1964). Polyarteritis and acute poststreptococcal glomerulonephritis. Annals of Internal Medicine, Vol.61, (July 1964), pp. 89-97, ISSN 0003-4819

Froehlich T., Sandifer S., Varma P. \& Testa F. (1999). Two cases of hypertension-induced reversible posterior leukoencephalopathy syndrome secondary to glomerulonephritis. Current Opinion in Pediatrics, Vol.11, No.6, (December 1999), pp. 512-518, ISSN 1040-8703

Fujinaga S., Ohtomo Y., Umino D., Mochizuki H., Takemoto M., Shimizu T., Yamashiro Y. \& Kaneko K. (2007). Pulmonary edema in a boy with biopsy-proven poststreptococcal glomerulonephritis without urinary abnormalities. Pediatric Nephrology, Vol.22, No.1, (January 2007), pp. 154-155, ISSN 0931-041X

Fux C., Bianchetti M., Jakob S. \& Remonda L. (2006). Reversible encephalopathy complicating post-streptococcal glomerulonephritis. Pediatric Infectious Disease Journal, Vol.25, No.1, (January 2006), pp. 85-87, ISSN 0891-3668

Garg R. (2001). Posterior leukoencephalopathy syndrome. Postgraduate Medical Journal, Vol.77, No.903, (January 2001), pp. 24-28, ISSN 0032-5473

Garrett P., Bass P., Atchley J., Theaker J. \& Dathan J. (1993). Wegener's granulomatosis and acute poststreptococcal glomerulonephritis. Nephrology Dialysis and Transplantation, Vol.8, No.5, pp. 454-455, ISSN 0931-0509

Geber M. (2007). Group A streptococcus, In: Nelson Textbook of Pediatrics, M.A. Greber, R.M. Kiegman, R.E. Behrman, H.B. Jenson \& B.F. Stanton, (Ed.), pp. 1135-1145, Saunders, ISBN 918-1-4160-2450-7, Philadelphia, USA

Gehrs B. \& Friedberg R. (2002). Autoimmune hemolytic anemia. American Journal of Hematology, Vol.69, No.4, (April 2002), pp. 258-271, ISSN 0361-8609

Gibney R., Reineck H., Bannayan G. \& Stein J. (1981). Renal lesions in acute rheumatic fever. Annals of Internal Medicine, Vol.94, No.3, (March 1981), pp. 322-326, ISSN 0003-4819

Gilboa N., McIntire S., Hopp L. \& Ellis D. (1993). Acute noncrescentic poststreptococcal glomerulonephritis presenting with pulmonary hemorrhage. Pediatric Nephrology, Vol.7, No.2, (April 1993), pp. 147-150, ISSN 0931-041X

Glozt D., Jouvin M., Nochy D., Druet P. \& Bariety J. (1991). Recurrent acute glomerulonephritis. American Journal of Kidney Diseases, Vol.17, No.2, (February 1991), pp. 228-230, ISSN 0272-6386

Goodyer P., de Chadarevian J. \& Kaplan B. (1978). Acute poststreptococcal glomerulonephritis mimicking Henoch-Schönlein purpura. Journal of Pediatrics, Vol.93, No.3, (September 1978), pp. 412-415, ISSN 0022-3476 
Goorno W., Ashworth C., \& Carter N. (1967). Acute glomerulonephritis with absence of abnormal urinary findings. Diagnosis by light and electron microscopy. Annals of Internal Medicine, Vol.66, No.2, (February 1967), pp. 345-353, ISSN 0003-4819

Greenbaum L., Kerlin B., Why S., Punzalan R., Trost B., Pan C. \& Scott J. (2003). Concurrent poststreptococcal glomerulonephritis and autoimmune hemolytic anemia. Pediatric Nephrology, Vol.18, No.12, (December 2003), pp. 1301-1303, ISSN 0931-041X

Grossman A., Ramanathan K. \& Fresco R. (1973). Acute glomerulonephritis with minimal urinary abnormalities presenting as hypertension. Clinical Pediatrics, Vol.12, No.4, (April 1973), pp. 250-254, ISSN 0009-9228

Gupta S., Goyal V. \& Talukdar B. (2010). Reversible posterior leukoencephalopathy syndrome in post streptococcal glomerulonephritis. Indian Pediatrics, Vol.47, No. 3, (March 2010), pp. 274-276, ISSN 0019-6061

Hinchey J., Chaves C., Appingnani B., Breen J., Pao L., Wang A., Pessin M., Lamy C., Mas J. \& Caplan L. (1996). A reversible posterior leukoencephalopathy syndrome. New England Journal of Medicine, Vol.334, No.8, (February 1996), pp. 494-500, ISSN 00284793

Hoyer J., Michael A., Fish A. \& Good R. (1967). Acute poststreptococcal glomerulonephritis presenting as hypertensive encephalopathy with minimal urinary abnormalities. Pediatrics, Vol.39, No.3, (March 1967), pp. 412-417, ISSN 0031-4005

Imanaka H., Eto S., Takei S., Yoshinaga M., Hokonohara A. \& Miyata K. (1995). Acute rheumatic fever and poststreptococcal acute glomerulonephritis caused by $\mathrm{T}$ serotype 12 Streptococcus. Acta Paediatrica Japonica, Vol.37, No.3, (June 1995), pp. 381-383, ISSN 0374-5600

Ingelfinger J., McCluskey R., Schneeberger E. \& Grupe W. (1977). Necrotizing arteritis in acute poststreptococcal glomerulonephritis. Journal of Pediatrics, Vol.91, No.2, (August 1997), pp. 228-232, ISSN 0022-3476

Izumi T., Hyodo T., Kikuchi Y., Imakiire T., Ikenoue T., Suzuki S., Yoshizawa N. \& Miura S. (2005). An adult with acute poststreptococcal glomerulonephritis complicated by hemolytic uremic syndrome and nephrotic syndrome. American Journal of Kidney Diseases, Vol.46, No.4, (October 2005), pp. E59-E63, ISSN 0272-6386

Kasahara T., Hayakawa H., Okubo S., Okugawa T., Kabuki N., Tomizawa S., \& Uchiyama M. (2001). Prognosis of acute poststreptococcal glomerulonephritis (APSGN) is excellent in children, when adequately diagnosed. Pediatrics International, Vol.43, No.4, (August 2001), pp. 364-367, ISSN 1442-200X

Kakkera D., Khan A., Bastawros M., Lao J. \& Nudel D. (1998). Acute rheumatic pancarditis associated with poststreptococcal acute glomerulonephritis: a patient report. Clinical Pediatrics, Vol.37, No.9, (September 1998), pp. 569-572, ISSN 0009-9228

Kandall S., Edelmann C. Jr \& Bernstein J. (1969). Acute poststreptococcal glomerulonephritis. A case with minimal urinary abnormalities. American journal of Diseases of Children, Vol.118, No.3, (September 1969), pp. 462-430, ISSN 0002-922X

Kaplan B. \& Esseltine D. (1978). Thrombocytopenia in patients with acute post-streptococcal glomerulonephritis. Journal of Pediatrics, Vol.93, No.6, (December 1978), pp. 974-976, ISSN 0022-3476

Kaplan R., Zwick D., Hellerstein S., Warady B. \& Alon U. (1993). Cerebral vasculitis in acute post-streptococcal glomerulonephritis. Pediatric Nephrology, Vol.7, No.2, (April 1993), pp. 194-195, ISSN 0931-041X 
Keir L. \& Coward R. (2011). Advances in our understanding of the pathogenesis of glomerular thrombotic microangiopathy. Pediatric Nephrology, Vol.26, No.4, (April 2011), pp. 523-533, ISSN 0931-041X

Kim P., Park S., Deung Y. \& Choi I. (1979). Second attack of acute poststreptococcal glomerulonephritis; reports of two cases. Yonsei Medical Journal, Vol.20, No.1, pp. 61-68, ISSN 0513-5796

Kobayashi O. Wada H. \& Okawa K. (1971). Extrarenal symptomatic glomerulonephritis in children. Acta Medica et Biologica, Vol.19, No.1, (June 1971), pp. 63-74, ISSN 05677734

Kujala G., Doshi H. \& Brick J. (1989). Rheumatic fever and poststreptococcal glomerulonephritis: a case report. Arthritis and Rheumatism, Vol.32, No.2, (February 1989), pp. 236-239, ISSN 0004-3591

Kula S., Saygili A., Tunaoğlu F. \& Olguntürk R. (2003). Acute poststreptococcal glomerulonephritis and acute rheumatic fever in the same patient: a case report and review of the literature. Anadolu Kardiyoloji Dergisi, Vol.3, No.3, (September 2003), pp. 272-274, ISSN 1302-8723

Kwong Y., Chan K. \& Chan M. (1987). Acute post-streptococcal glomerulonephritis followed shortly by acute rheumatic fever. Postgraduate Medical Journal, Vol.63, No.737, (March 1087), pp. 209-210, ISSN 0032-5473

Laube G., Sarkissian A., Hailemariam S., Neuhaus T. \& Leumann E. (2001). Simultaneous occurrence of the haemolytic uraemic syndrome and acute post-infectious glomerulonephritis. European Journal of Pediatrics, Vol.160, No.3, (March 2001), pp. 173-176, ISSN 0340-6199

Leiba H., Barash J. \& Pollack A. (1998). Poststreptococcal uveitis. American Journal of Ophthalmology, Vol.126, No.2, (August 1998), pp. 317-318, ISSN 0002-9394

Lin W., Lo W. , Ou T. \& Wang C. (2003). Haematuria, transient proteinuria, serpiginousborder skin rash, and cardiomegaly in a 10-year-old girl. European Journal of Pediatrics, Vol.162, No.9, (September 2003), pp. 655-657, ISSN 0340-6199

Lucus S. \& Moxham J. (1978). Recurrent vasculitis associated with beta-haemolytic streptococcal infections. British Medical Journal, Vol.1. No.6123, (May 1978), pp. 1323, ISSN 0007-1447

Mackie S. \& Keat A. (2004). Poststreptococcal reactive arthritis: what is it and how do we know? Rheumatology, Vol.43, No.8, (August 2004), pp. 949-954, ISSN 1462-0324

Maruyama K., Arai H., Ogawa T., Hoshino M., Tomizawa S. \& Morikawa A. (1995). C9 deficiency in a patient with poststreptococcal glomerulonephritis. Pediatric Nephrology, Vol.9, No.6, (December 1995), pp. 746-748, ISSN 0931-041X

Masuda M, Nakanishi K., Yoshizawa N., Iijima K. \& Yoshikawa N. (2003). Group A streptococcal antigen in the glomeruli of children with Henoch-Schönlein nephritis. American Journal of Kidney Diseases, Vol.41, No.2, (February 2003), pp. 366-370, ISSN 0272-6386

Matsell D., Baldree L., DiSessa T., Gaber L. \& Stapleton F. (1990). Acute poststreptococcal glomerulonephritis and acute rheumatic fever: occurrence in the same patient. Child Nephrology and Urology, Vol.10, No.2, pp. 112-114, ISSN 1012-6694

Matsukura H., Ohtsuki A., Fuchizawa T. \& Miyawaki T. (2003). Acute poststreptococcal glomerulonephritis mimicking Henoch-Schönlein purpura. Clinical Nephrology, Vol.59, No.1, (January 2003), pp. 64-65, ISSN 0301-0430 
Medani C., Pearl P. \& Hall-Craggs M. (1987). Acute renal failure, hemolytic anemia, and thrombocytopenia in poststreptococcal glomerulonephritis. Southern Medical Journal, Vol.80, No.3, (March 1987), pp. 370-373, ISSN 0038-4348

Muguruma T., Koyama T., Kanadani T., Furujo M., Shiraga H. \& Ichiba Y. (2000). Acute thrombocytopenia associated with post-streptococcal acute glomerulonephritis. Journal of Paediatrics and Child Health, Vol.36, No.4, (August 2000), pp. 401-402, ISSN 1034-4810

Niewold T. \& Ghosh A. (2003). Post-streptococcal reactive arthritis and glomerulonephritis in an adult. Clinical Rheumatology, Vol.22, No.4-5, (October 2003), pp. 350-352, ISSN 070-3198

Nordby J. (1997). Neurological presentation of poststreptococcal glomerulonephritis. Clinical Pediatrics, Vol.36, No.2, (February 1997), pp. 105-108, ISSN 0009-0228

Oda T., Yoshizawa N., Yamakami K., Tamura K., Kuroki A., Sugisaki T., Sawanobori E., Higashida K., Ohtomo Y., Hotta O., Kumagai H. \& Miura S. (2010). Localization of nephritis-associated plasmin receptor in acute poststreptococcal glomerulonephritis. Human Pathology, Vol.41, No.9, (September 2010), pp. 12761285, ISSN 0046-8177

Öner A., Atalay S., Karademir S. and Pekuz O. (1993). Acute poststreptococcal glomerulonephritis followed by acute rheumatic carditis: an unusual case. Pediatric Nephrology, Vol.7, No.5, (October 1993), pp. 592-593, ISSN 0931-041X

Onisawa S., Morishima N. \& Ichimura T. (1989). Concurrent poststreptococcal acute glomerulonephritis and Schönlein-Henoch purpura. Acta Paediatrica Japonica, Vol31, No.4, (August 1989), pp. 487-492, ISSN 0374-5600

Özcakar Z., Ekim M., Fitoz S., Teber S., Hizel S., Acar B., Yüksel S. \& Yalcinkaya F. (2004). Hypertension induced reversible posterior leukoencephalopathy syndrome: a report of two cases. European Journal of Pediatrics, Vol.163, No.12, (December 2004), pp. 728-730, ISSN 0340-6199

Pais P., Kump T. \& Greenbaum L. (2008). Delay in diagnosis in poststreptococcal glomerulonephritis. Journal of Pediatrics, Vol.153, No.4, (October 2008), pp. 560-564, ISSN 1687-9740

Papiris S., Manali E., Kalomenidis I., Kapotsis G., Karakatsani A. \& Roussos C. (2007). Bench-to-bedside review: pulmonary-renal syndromes - an update for the intensivist. Critical Care, Vol.11, No.3, (May 2007), pp. 213, ISSN 1364-8535

Proesmans W. (1996). Haemolytic uremic syndrome superimposed on acute glomerulonephritis. Pediatric Nephrology, Vol.10, No.5, (October 1996), pp. 679, ISSN 0931-041X

Psaila B. \& Bussel J. (2007). Immune thrombocytopenic purpura. Hematology Oncology Clinics of North America, Vol.21, No.4, (August 2007), pp. 743-759, ISSN 0889-8588

Ramberg R. (1947). The prognosis for acute nephritis. Acta Medica Scandinavica, Vol.127, No.4, (May 1947), pp. 396-423, ISSN 0001-6101

Ritt M., Campean V., Amann K., Heider A., Griesbach D. \& Veelken R. (2006). Transient encephalopathy complicating poststreptococcal glomerulonephritis in an adult with diagnostic findings consistent with cerebral vasculitis. American Journal of Kidney Diseases, Vol.48, No.3, (September 2006), pp. 489-494, ISSN 0272-6386 
Rizkallah M., Ghandour M., Sabbah R. \& Akhtar M. (1984). Acute thrombocytopenic purpura and poststreptococcal acute glomerulonephritis in a child. Clinical Pediatrics, Vol.23, No.10, (October 1984), pp. 581-583, ISSN 0009-9228

Robson W. \& Leung A. (1994). Henoch-Schönlein purpura. Advances in Pediatrics, Vol.41, pp. 163-194, ISSN 0065-3101

Rodriguez-Iturbe B. \& Musser J. (2008). The current state of poststreptococcal glomerulonephritis. Journal of the American Society of Nephrology, Vol.19, No.10, (October 2008), pp. 1855-1864, ISSN 1046-6673

Rodriguez-Iturbe B. \& Mezzani S. (2009). Acute postinfectious glomerulonephritis, In: Pediatric Nephrology, Avner E., Harman W., Niaudet P., Yoshikawa N., (Ed.), pp. 743-755, Springer Verlag, ISBN 978-3-540-76327-7, Berlin

Rosenberg H., Donoso P., Vial S., Carranza S. \& Romero P. (1984). Clinical and morphological recovery between two episodes of acute glomerulonephritis: a light and electron microscopic study with immunofluorescence. Clinical Nephrology, Vol.21, No.6, (June 1984), pp. 350-354, ISSN 0301-0430

Rovang R., Zawada E. Jr, Santella R., Jaqua R., Boice J. \& Welter R. (1997). Cerebral vasculitis associated with acute post-streptococcal glomerulonephritis. American Journal of Nephrology, Vol.17. No.1, pp. 89-92, ISSN 0250-8095

Roy S. III, Wall H. \& Etteldorf J. (1969). Second attacks of acute glomerulonephritis. Journal of Pediatrics, Vol.75, No.5, (November 1969), pp. 758-767, ISSN 0022-3476

Said R., Hussein M. \& Hassan A. (1986). Simultaneous occurrence of acute poststreptococcal glomerulonephritis and acute rheumatic fever. American Journal of Nephrology, Vol.6, No.2, pp. 146-148, ISSN 0250-8095

Sanjad S., Tolaymat A. \& Levin S. (1977). Acute glomerulonephritis in children: a review of 153 cases. Southern Medical Journal, Vol.70, No.10, (October 1977), pp. 1202-1206, ISSN 0038-4348

Siebels M., Andrassy K., Waldherr R. \& Ritz E. (1995). Hemolytic uremic syndrome complicating postinfectious glomerulonephritis in the adult. American Journal of Kidney Diseases, Vol.25, No.2, (February 1995), pp. 336-339, ISSN 0272-6386

Sieck J., Awad M., Saour J., Ali H., Qunibi W. \& Mercer E. (1992). Concurrent poststreptococcal carditis and glomerulonephritis: serial echocardiographic diagnosis and follow-up. European Heart Journal, Vol.13, No.12, (December 1992), pp. 17201723, ISSN 0195-668X

Sinha R., Al-Alsheikh K., Prediville J., Magil A. \& Matsell D. (2007). Acute rheumatic fever with concomitant poststreptococcal glomerulonephritis. American Journal of Kidney Diseases, Vol.50, No.1, (July 2007), pp. A33-A35, ISSN 0272-6386

Soylu A., Kavukçu S., Türkmen M. \& Akbaş Y. (2001). Posterior leukoencephalopathy syndrome in poststreptococcal acute glomerulonephritis. Pediatric Nephrology, Vol.16, No.7, (July 2001), pp. 601-603, ISSN 0931-041X

Steer A. \& Carapetis J. (2009). Acute rheumatic fever and rheumatic heart disease in indigenous populations. Pediatric Clinics of North America, Vol. 56, No.6, (December 2009), pp. 1410-1419, ISSN 0031-3955

Sugimoto T., Takeda N., Sakaguchi M., Koyama T., Isoya E., Yagi Y., Uzu T. \& Kashiwagi A. (2008). A case of post-streptococcal reactive arthritis and acute nephritis after bacterial endophthalmitis due to Streptococcus pyogenes. Rheumatology International, Vol.28, No.12, (October 2008), pp. 1285-1286, ISSN 0172-8172 
Sung H., Lim C., Shin M., Kim B., Kim Y., Song H., Kim S.,Choi E., Chang Y. \& Bang B. (2007). A case of post-streptococcal glomerulonephritis with diffuse alveolar hemorrhage. Journal of Korean Medical Science, Vol. 22, No.6, (December 2007), pp. 1074-1078, ISSN 1011-8934

Talarico H. \& Rubens D. (1990). Gallbladder wall thickening in acute pyelonephritis. Journal of Clinical Ultrasound, Vol.18, No.8, (October 1990), pp. 653-657, ISSN 0091-2751

Tan P., Yadin O., Kleinman K., Gura V. \& Cohen A. (1998). Simultaneous postinfectious glomerulonephritis and thrombotic microangiopathy: a renal biopsy study. American Journal of Kidney Diseases, Vol.31, No.3, (March 1998), pp. 513-520, ISSN 0272-6386

Tasic V. \& Polenakovic M. (2003). Thrombocytopenia during the course of acute poststreptococcal glomerulonephritis. Turkish Journal of Pediatrics, Vol.45, No.2, (April-June 2003), pp. 148-151, ISSN 0041-4301

Tokura T., Morita Y., Yorimitsu D., Horike H., Sasaki T. \& Kashihara N. (2008). Cooccurrence of poststreptococcal reactive arthritis and acute glomerulonephritis. Modern Rheumatology, Vol.18, No.5, (October 2008), pp. 526-528, ISSN 1439-7595

Traverso F., Martini F., Banchi L., Maritato F. \& Fazio B. (1997). Vasculitic neuropathy associated with beta-haemolytic streptococcal infection: a case report. Italian Journal of Neurological Sciences, Vol.18, No.2, pp. 105-107, ISSN 0392-0461

Ur Rehman S., Anand S., Reddy A., Backhous O., Mohamed M., Mahomed I., Atkins A. \& James T. (2006). Poststreptococcal syndrome uveitis: a descriptive case series and literature review. Ophthalmology, Vol.113, No.4, (April 2006), pp. 701-706, ISSN 0161-6420

van Breda Vriesman A., Engelbrecht M., Smithuis R. \& Puylaert J. (2007). Diffuse gallbladder wall thickening: differential diagnosis. American Journal of Roentogenology, Vol.188, No.2, (February 2007), pp. 459-501, ISSN 0361-803X

van der Helm-van Mil A. (2010). Acute rheumatic fever and poststreptococcal reactive arthritis reconsidered. Current Opinion in Rheumatology, Vol.22, No.4, (July 2010), pp. 437-442, ISSN 1040-8711

Velhote V., Saldanha L., Malheiro P., Praxedes J., Penna D., Marcondes M. \& Sabbaga E. (1986). Acute glomerulonephritis: three episodes demonstrated by light and electron microscopy, and immunofluorescence studies - a case report. Clinical Nephrology, Vol.26, No.6, (December 1986), pp. 307-310, ISSN 0301-0430

Watanabe T. \& Baba Y. (2009). Gallbladder wall thickening in a patient with acute poststreptococcal glomerulonephritis. European Journal of Pediatrics, Vol.168, No.6, (June 2009), pp. 717-719, ISSN 0340-6199

Watanabe T. \& Yoshizawa N. (2001). Recurrence of acute poststreptococcal glomerulonephritis. Pediatric Nephrology, Vol.16, No.7, (July 2001), pp. 598-600, ISSN 0931-041X

Wong W. \& Morris M. (2001). Cerebral vasculitis in a child following post-streptococcal glomerulonephritis. Journal of Paediatrics and Child Health, Vol.37, No. 6, pp. 597-599, ISSN 1034-4810

Yamakami K., Yoshizawa N., Wakabayashi K., Takeuchi A., Tadakuma T. \& Boyle M. (2000). The potential role for nephritis-associated plasmin receptor in acute poststreptococcal glomerulonephritis. Methods, Vol.21, No.2, (June 2000), pp. 185197, ISSN 1046-2023 
Yoshizawa N. (2000). Acute glomerulonephritis. Internal Medicine, Vol.39, No.9, (September 2000), pp. 687-694, ISSN 0918-2918

Yoshizawa N., Yamakami K., Fujino M., Oda T., Tamura K., Matsumoto K., Sugisaki T., \& Boyle M. (2004). Nephritis-associated plasmin receptor and acute poststreptococcal glomerulonephritis: characterization of the antigen and associated immune response. Journal of the American Society of Nephrology, Vol.15, No.7, (July 2004), pp. 1785-1793, ISSN 1046-66 


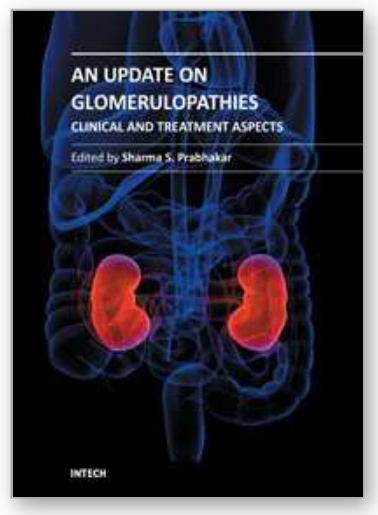

\author{
An Update on Glomerulopathies - Clinical and Treatment Aspects \\ Edited by Prof. Sharma Prabhakar
}

ISBN 978-953-307-673-7

Hard cover, 468 pages

Publisher InTech

Published online 02, November, 2011

Published in print edition November, 2011

An Update on Glomerulopathies - Clinical and Treatment Aspects is a systemic overview of recent advances in clinical aspects and therapeutic options in major syndromes of glomerular pathology. The book contains twenty four chapters divided conveniently into five sections. The first section deals with primary glomerulopathies, and the second section is devoted to glomerulopathies complicating infectious conditions. The third section deals with systemic autoimmune disorders and vasculitides which constitute major causes of glomerular disease and often renal failure. The fourth section includes chapters discussing the glomerular involvement in some major metabolic and systemic conditions. The final section has chapters which relate to some general aspects of glomerular diseases. This book will form an excellent reference tool for practicing and academic nephrology community.

\title{
How to reference
}

In order to correctly reference this scholarly work, feel free to copy and paste the following:

Toru Watanabe (2011). Atypical Clinical Manifestations of Acute Poststreptococcal Glomerulonephritis, An Update on Glomerulopathies - Clinical and Treatment Aspects, Prof. Sharma Prabhakar (Ed.), ISBN: 978-953307-673-7, InTech, Available from: http://www.intechopen.com/books/an-update-on-glomerulopathies-clinicaland-treatment-aspects/atypical-clinical-manifestations-of-acute-poststreptococcal-glomerulonephritis

\section{INTECH}

open science | open minds

\author{
InTech Europe \\ University Campus STeP Ri \\ Slavka Krautzeka 83/A \\ 51000 Rijeka, Croatia \\ Phone: +385 (51) 770447 \\ Fax: +385 (51) 686166 \\ www.intechopen.com
}

\author{
InTech China \\ Unit 405, Office Block, Hotel Equatorial Shanghai \\ No.65, Yan An Road (West), Shanghai, 200040, China \\ 中国上海市延安西路65号上海国际贵都大饭店办公楼 405 单元 \\ Phone: +86-21-62489820 \\ Fax: +86-21-62489821
}


(C) 2011 The Author(s). Licensee IntechOpen. This is an open access article distributed under the terms of the Creative Commons Attribution 3.0 License, which permits unrestricted use, distribution, and reproduction in any medium, provided the original work is properly cited. 